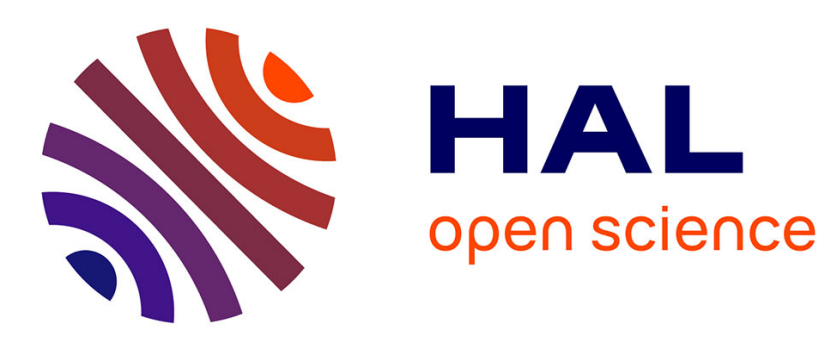

\title{
The influence of Saharan agro-pastoralism on the structure and dynamics of acacia stands
}

Julien M Blanco, Didier Genin, Stéphanie M Carrière

\section{To cite this version:}

Julien M Blanco, Didier Genin, Stéphanie M Carrière. The influence of Saharan agro-pastoralism on the structure and dynamics of acacia stands. Agriculture, Ecosystems and Environment, 2015, 213, pp.21-31. 10.1016/j.agee.2015.07.013 . hal-01388053

\section{HAL Id: hal-01388053 https://hal.science/hal-01388053}

Submitted on 2 Nov 2016

HAL is a multi-disciplinary open access archive for the deposit and dissemination of scientific research documents, whether they are published or not. The documents may come from teaching and research institutions in France or abroad, or from public or private research centers.
L'archive ouverte pluridisciplinaire HAL, est destinée au dépôt et à la diffusion de documents scientifiques de niveau recherche, publiés ou non, émanant des établissements d'enseignement et de recherche français ou étrangers, des laboratoires publics ou privés. 
Running title: Saharan acacia stands and agro-pastoralism

2

3

Title: The influence of Saharan agro-pastoralism on the structure and dynamics of acacia stands

Authors: Julien BLANCO ${ }^{\mathrm{a}, 1}$, Didier GENIN ${ }^{\mathrm{b}}$, Stéphanie M. CARRIERE ${ }^{\mathrm{a}}$

a IRD, UMR-220 GRED, 911, Av. Agropolis, BP 64501, 34394 Montpellier Cedex 5, France, julien.blanco@ird.fr, stephanie.carriere@ird.fr

${ }^{\mathrm{b}}$ IRD and Aix-Marseille University, UMR 151 LPED, 3 place Victor Hugo, 13331 Marseille

Cedex 3 France, didier.genin@univ-amu.fr

${ }^{1}$ Corresponding author: Phone: (33) 4676369 82; Fax: (33) 467638778

\section{Summary}

Trees play a crucial role in drylands, where they are often considered as keystone species for ecosystems and for local livelihoods. In particular in the Saharan region, Vachellia tortilis subsp. raddiana (ex. Acacia tortilis subsp. raddiana) are multi-purpose acacia trees for people and contribute to the overall ecosystem functioning. Despite progress in research, acacia stands in this region are poorly documented and little is known on their interactions with human Saharan populations. On the basis of a multidisciplinary approach, the aim of this study was to assess the structure and dynamics of Saharan acacia stands in south-western Morocco and the influence of human activities and practices. Interviews and participant observations were performed in two villages and individual acacia trees were measured in contrasting topography, microhabitat and land use situations. The acacia stands were located in cultivated and browsed areas where trees were used and shaped in the framework of human subsistence activities. In this context, the low-density acacia stands (4.8 trees/ha) showed high regeneration (47.8\%) and recruitment rates, and low mortality (3.3\%). Land use had more effect on stand structures than topography or microhabitat. Tree regeneration and density were especially high in cultivated areas. Most trees showed traces of pruning (60.3\% of them) and debarking (33.9\%), but with no correlation with tree mortality. Environmental and anthropogenic factors jointly contributed to the structure and dynamics of acacia stands, and no threat to their sustainability was observed. 
35 Even though further investigation would be required to better distinguish environmental and

45 anthropogenic factors and to draw long-term conclusions, our results suggest that Saharan agropastoralism activities are not necessarily incompatible with acacia tree conservation, contrary to the commonly admitted postulate in Morocco.

\section{Keywords}

Vachellia tortilis subsp. raddiana; acacia; drylands; local practices; agro-pastoral systems; tree measurement; Morocco. 
Drylands - defined as areas with an aridity index lower than 0.65 - cover about $41 \%$ of the Earth's land surface and harbour $38 \%$ of the global human population (MEA, 2005). Drylands are environmentally and socially vulnerable, in particular in the face of desertification, that is irreversible land degradation resulting from multiple climatic and anthropogenic factors (MEA, 2005). Despite early studies that highlighted worrying rates of desertification and identified humans as the main cause (Lamprey, 1975), recent research has cast doubt on these conclusions (Helldén and Tottrup, 2008). A better understanding of climatic variability, socio-economic processes and political dimensions, associated with a shift in rangeland ecology paradigms, have provided a basis for highlighting the non-uniformity of desertification and for more nuanced conclusions on the role of human activities in the face of climatic variations (Herrmann and Hutchinson, 2005). Yet desertification remains subject to scientific debate mainly because finding accurate indicators of long-term changes - such as "slow" variables (Carpenter and Turner, 2001) - is challenging. Considering the crucial ecological role of trees in dryland ecosystems (Belsky et al., 1989), monitoring woodlands in drylands may constitute accurate "slow" indications of potential degradation and desertification.

Vachellia tortilis (Forssk.) Galasso \& Banfi subsp. raddiana (Savi) Kyal. \& Boatwr. - ex Acacia tortilis (Forssk.) Hayne subsp. raddiana (Savi) Brenan (Kyalangalilwa et al., 2013); further noted $V$. raddiana or acacia tree in this paper - is the most widespread native acacia tree in the Saharan region. Considered as a keystone species (Munzbergova and Ward, 2002; Noumi et al., 2012), V.. raddiana improves soil fertility, decreases potential evapo-transpiration and consequently affects the establishment, development and survival of other plants (Abdallah et al., 2008; Noumi and Chaieb, 2012). In addition, V. raddiana is a precious source of forage, fuel wood and other materials (Grouzis and Le Floc'h, 2003). Hence, conserving V. raddiana is a crucial challenge in the Saharan region, both for its role in terms of ecosystem conservation and for the preservation of local livelihoods. Nevertheless, the conservation of $V$. raddiana still remains uncertain as the literature has reported contrasting conclusions. On the one hand, $V$. raddiana stands showed positive trends in Israel (Lahav-Ginott et al., 2001), in Algeria (Sahraoui et al., 1996) and in Tunisia (Noumi et al., 2010b). On the other hand, negative trends were reported in Egypt (Andersen and Krzywinski, 2007), in Israel (Ward and Rohner, 1997) and in Tunisia (Noumi and Chaieb, 2012). These contrasting dynamics are associated with contrasted local conditions in terms of rainfall regime (Sahraoui et al., 1996), runoff and water flux (BenDavid-Novak and Schick, 1997; Ward and Rohner, 1997; Wiegand et al., 2000b), 
seed predation by insects (Derbel et al., 2007), browsing intensity (Noumi et al., 2010b) or anthropogenic exploitation (Andersen and Krzywinski, 2007). Given such local variations, extending the carrying out of local studies is crucial to fill the knowledge gap on the dynamics of $V$. raddiana at regional scale and to better assess conservation priorities.

In Morocco, no study has investigated the structure and dynamics of $V$. raddiana stands. Furthermore, most Moroccan V. raddiana stands are located outside protected areas and are embedded in local agro-pastoral and pastoral systems. Except for some descriptions of local practices for $V$. raddiana in Egypt (Andersen et al., 2014; Hobbs et al., 2014), no study has addressed the effects of local practices, uses or management on the structure and dynamics of $V$. raddiana stands. Such studies may help to achieve a better understanding of coupled HumanEnvironment systems in drylands (Reynolds et al., 2007) in the interests of sounder and more efficient conservation methods.

The aim of the present study was (1) to assess the structure and dynamics of $V$. raddiana stands, and (2) to identify human activities and related practices and their influence on tree stands. We hypothesized that, in complement to environmental variables, human activities and practices may substantially influence the structure and the dynamics of $V$. raddiana stands. To test this prediction, we adopted a multidisciplinary approach in an agro-pastoral landscape and in two neighbouring villages in south-western Morocco. We combined (1) socio-anthropological investigations in order to identify and characterize human activities and practices related to $V$. raddiana trees, and (2) ecological measurements to assess the structure and dynamics of $V$. raddiana stands subjected to human practices.

\section{Materials and methods}

\subsection{STUDY SITE}

This study took place in south-western Morocco (Fig. 1) in the north-western Saharan biogeographical zone (Le Houérou, 1990). With mean annual rainfall of $112 \mathrm{~mm}$ and average temperature of $19.6^{\circ} \mathrm{C}$, the climate is arid with mild winters, due the proximity of the Atlantic Ocean. In this area, three geomorphological formations dominate (Monteil, 1948): (1) rocky terraces superficially covered with sand and gravel and criss-crossed by sandy runnels; (2) a plain with deep alluvial soils and local sand accumulations from wind erosion, transected by dry riverbeds; and (3) high-sloped rocky inselbergs forming part of the Anti-Atlas Mountains. The vegetation is characteristic of the Saharan eco-region with $V$. raddiana as the dominant 
tree species and Hammada scoparia (Pomel) Iljin as the dominant shrub, locally associated with Panicum turgidum Forssk. in sandy riverbeds, Convolvulus trabutianus Schweinf. \& Muschler in terraces and Ziziphus lotus (L.) Lam in the plain (Msanda et al., 2002). Acacia trees only colonize the plain and the terrace runnels.

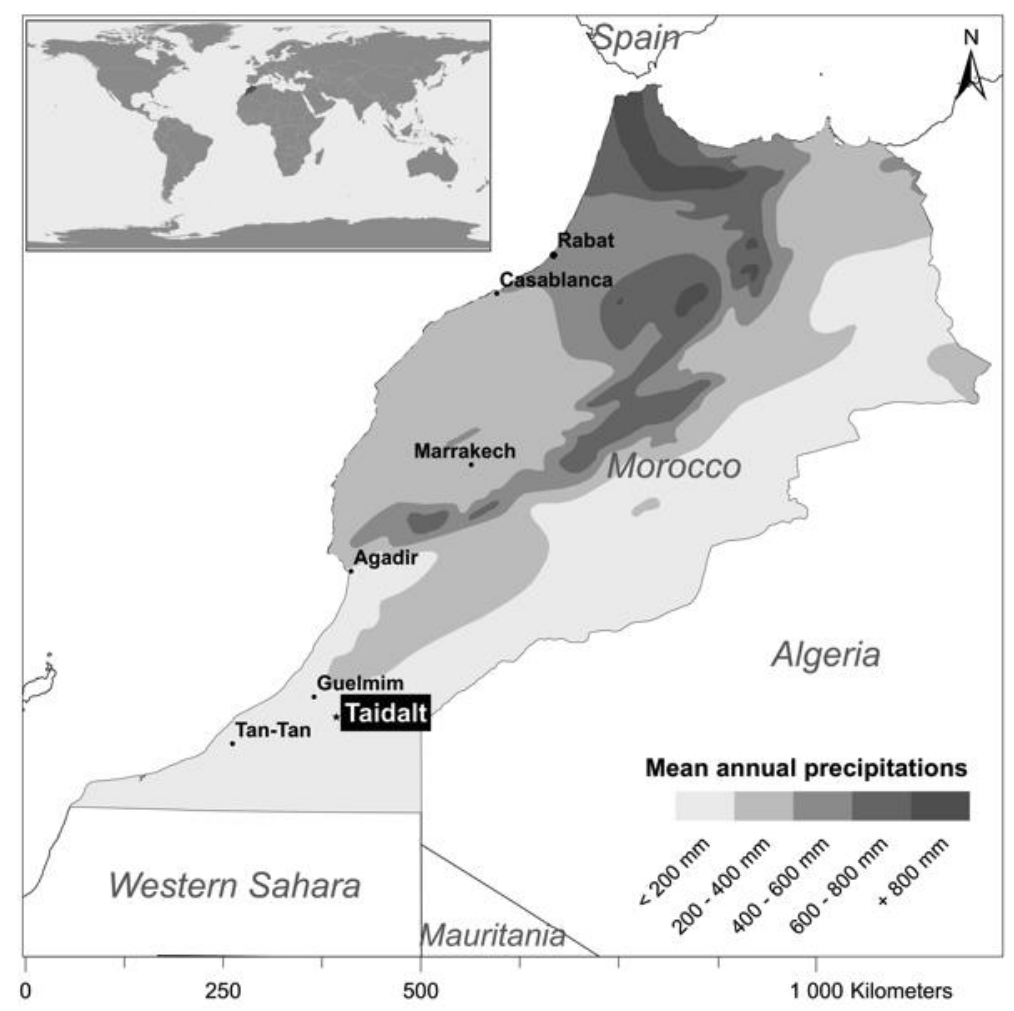

Figure 1: Study site location (Taidalt village) in south-western Morocco, province of Guelmim.

Two types of human subsistence activities predominate in the acacia woodlands. Firstly, plains and major riverbeds are occasionally used for the cultivation of rain-fed cereals (maize, wheat and barley) (Monteil, 1948). Farmers cultivate flooded areas after episodic rains. Secondly, there are semi-nomadic and settled livestock farming units of goats, sheep and dromedaries, for which acacia woodlands constitute a key rangeland component. In contrast to certain pastoral systems of the Atlas Mountains of Morocco (Genin and Simenel, 2011), no specific rules aimed at forbidding the herds' access to parts of the rangeland for a given period in order to preserve resources were observed. The only grazing restriction concerns sown fields, and ends after harvesting. Acacia woodlands are thus common rangelands, occasionally used for cereal cultivation in suitable areas. Neighbouring villagers and semi-nomads also harvest fuel wood, raw materials or medicines. 


\subsection{RESEARCH METHODS}

137

138

139

140

141

142

143

144

145

146

147

Seven one-month stays at different seasons of the first author in the El Borj and Taidalt villages from February 2013 to June 2014 enabled the identification of (1) human activities and practices related to acacia stands and (2) the place and schedule of these activities. Information was obtained from semi-nomads and settlers through semi-structured and informal interviews, participative observation and transects. Interviews focused on local uses and practices related to the $V$. raddiana tree. In particular, farmers were asked about the role of $V$. raddiana in crop fields and how they were managing trees. Herders and shepherds were questioned on the way they used and integrated $V$. raddiana within the framework of their pastoral activities. In addition to interviews, a total of 25 days between March 2013 and June 2014 were dedicated to participative observation, with a diverse panel of farmers, charcoal producers and herders. Livestock browsing is a structuring activity in arid environments, both for human societies and ecosystems. Nevertheless, the unpredictability and stochasticity of pastoral systems in drylands - including opportunistic behaviour, mobility, livestock variations, etc. (Niamir-Fuller, 1998) - challenge quantitative assessment from snapshot studies and the relevance of certain indicators such as the pastoral pressure. Furthermore, because of the absence of any unbrowsed area in the study site, assessing the impact of browsing on the vegetation without long-term experimental procedures was impossible. Thus our investigations focused on understanding general spatio-temporal patterns of livestock management and on identifying the nature of human practices related to pastoral activities. Interviews with the local forester at the beginning and at the end of the research also helped to confirm information obtained from villagers and observations. A general land use map of the study zone was compiled, based on geomorphology and main human activity (Fig. 2). A set of measurable indicators of the influence of human practices on $V$. raddiana trees, at the individual and stand scales, was determined (Table 1). 

measurable indicators and indexes

\begin{tabular}{|c|c|c|c|c|}
\hline Activities & Related practices & Purposes & $\begin{array}{c}\text { Measurable } \\
\text { indicator }\end{array}$ & $\begin{array}{c}\text { Corresponding index } \\
\text { influenced by the } \\
\text { practice }\end{array}$ \\
\hline \multirow[b]{2}{*}{ Agriculture } & $\begin{array}{l}\text { Pruning and } \\
\text { trimming }\end{array}$ & $\begin{array}{l}\text { Shaping trees for } \\
\text { shade }\end{array}$ & $\begin{array}{l}\text { Number of visible } \\
\text { scars }\end{array}$ & $P I$ (pruning intensity) \\
\hline & Tree removal & $\begin{array}{l}\text { Controlling tree } \\
\text { density inside } \\
\text { fields }\end{array}$ & Tree density & $\begin{array}{l}R \text { (distance to the nearest } \\
\text { tree) } \\
\lambda \text { (calculated tree density }\end{array}$ \\
\hline \multirow{3}{*}{$\begin{array}{l}\text { Livestock } \\
\text { farming }\end{array}$} & Leaves hanging & Feeding animals & $\begin{array}{l}\text { State of the tree } \\
\text { foliage }\end{array}$ & GI (Greenness index) \\
\hline & Pods hanging & Feeding animals & Pods number & $\begin{array}{l}\text { TRR (Total regeneration } \\
\text { rate) } \\
E R R \text { (Established } \\
\text { regeneration rate) }\end{array}$ \\
\hline & Debarking & Feeding animals & Tree bark state & $\begin{array}{l}D I \text { (debarking intensity) } \\
D P \text { (debarking } \\
\text { probability) }\end{array}$ \\
\hline \multirow{2}{*}{$\begin{array}{l}\text { Wood } \\
\text { harvesting }\end{array}$} & $\begin{array}{l}\text { Pruning and } \\
\text { trimming }\end{array}$ & $\begin{array}{l}\text { Firewood and } \\
\text { charcoal } \\
\text { production }\end{array}$ & $\begin{array}{l}\text { Number of visible } \\
\text { scars }\end{array}$ & $P I$ \\
\hline & Felling entire tree & $\begin{array}{l}\text { Charcoal } \\
\text { production }\end{array}$ & $\begin{array}{l}\text { Number of visible } \\
\text { stumps }\end{array}$ & $\begin{array}{l}\text { Count of the number of } \\
\text { visible stumps }\end{array}$ \\
\hline \multirow{4}{*}{ Medication } & Leaves harvest & $\begin{array}{l}\text { Medicine } \\
\text { preparation }\end{array}$ & $\begin{array}{l}\text { State of the tree } \\
\text { foliage }\end{array}$ & GI \\
\hline & $\begin{array}{l}\text { Gum exudates } \\
\text { collect }\end{array}$ & $\begin{array}{l}\text { Medicine and tea } \\
\text { preparation }\end{array}$ & $\begin{array}{l}\text { No measurable } \\
\text { impact on trees }\end{array}$ & - \\
\hline & Pods hanging & $\begin{array}{l}\text { Medicine } \\
\text { preparation }\end{array}$ & Pods number & $\begin{array}{l}T R R \\
E R R\end{array}$ \\
\hline & Debarking & $\begin{array}{l}\text { Medicine } \\
\text { preparation }\end{array}$ & Tree bark state & $\begin{array}{l}D I \\
D P\end{array}$ \\
\hline
\end{tabular}

\subsection{SAMPLING DESIGN}

The delimitation of $V$. raddiana sparse stands required the preliminary mapping of tree density from three high-resolution Digital Globe satellite images, extracted from Google Earth and dated February 2011. Two images (covering $62 \mathrm{~km}^{2}$ ) covered the plain, and the third one (22 $\mathrm{km}^{2}$ ) the terraces. The detection of individual tree canopies was performed under the ArcMap 10.0 software, resulting in three tree density maps used to implement the sampling design (Fig. 2). A total of 120 sampling points were randomly computed in order to take into account the population heterogeneity and to have the same number of points on each map and in each density class. The sample was thus stratified according to topography and tree density, and represented contrasted land use modalities and microhabitats. It consequently allowed testing the effect of environmental (topography and microhabitat) and of anthropogenic (land use) factors on the structure and dynamics of acacia stands. 


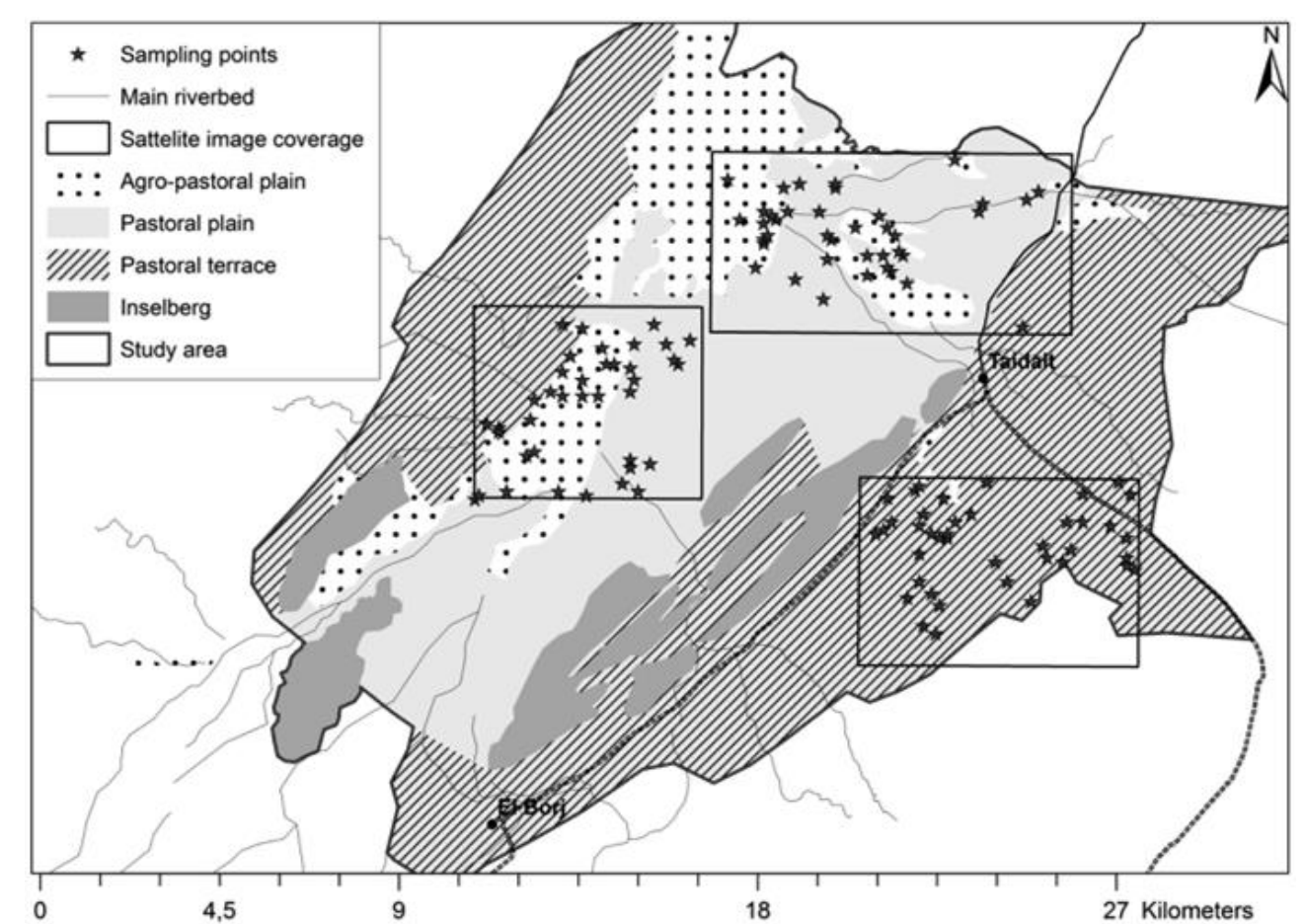

Figure 2: Land use modalities and sampling design distribution in the study area.

\subsection{TREE INVENTORY AND MEASUREMENT}

Sampling points were identified in the field with a Garmin 62 GPS. The Point-Centred Quarter Method (PCQM) was chosen for its accuracy regardless of stem density heterogeneity (Sparks et al., 2002) and for its feasibility for a single operator. PCQM consists in the delimitation of four quarters (here delimited according to the cardinal points) and in the measurement in each quarter of the nearest tree from the centre (Fig. 3). 


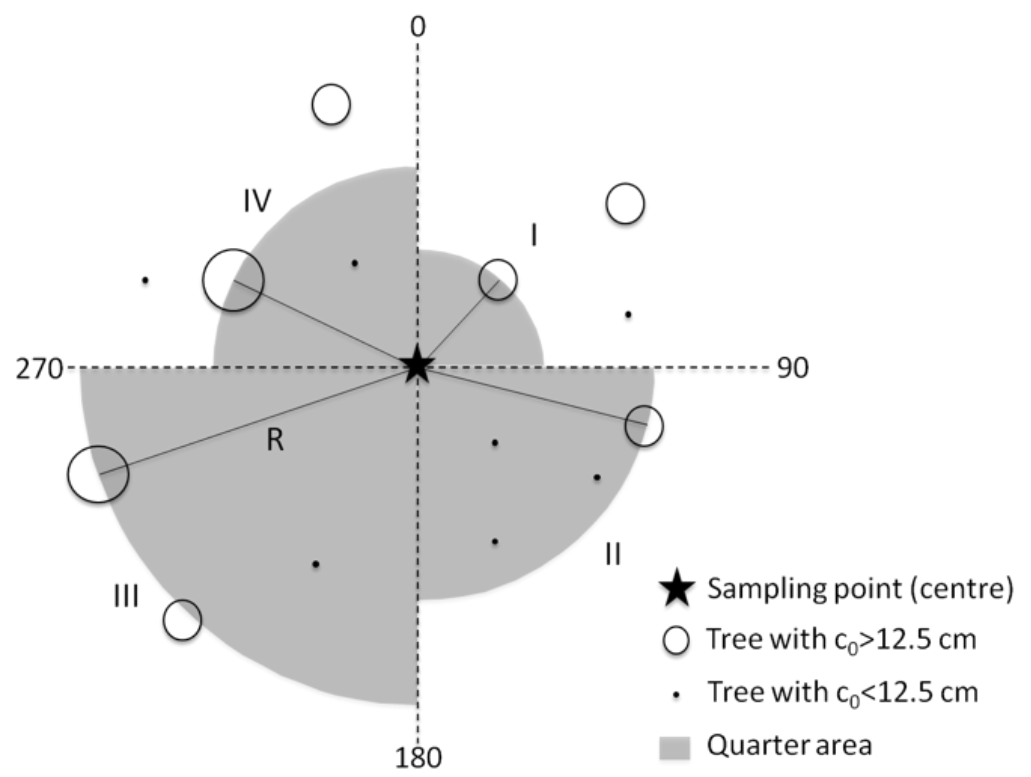

Figure 3: PCQM-plot design. Distances of the nearest tree from the centre $(R)$ define quarter area. One tree was measured per quarter; understory composition, regeneration and stumps counts concern the whole grey area.

The nearest tree (with a circumference at ground level $c_{0}>12.5 \mathrm{~cm}$ ) was located and its distance $R$ from the centre was measured with a tape for $R<30 \mathrm{~m}$ or was calculated with the GPS for $R>30 \mathrm{~m}$. The tree species was identified and we measured the total height $(H)$, the circumference at ground level $\left(c_{0}\right)$ of every tree stem with $\mathrm{c}_{0}>12.5 \mathrm{~cm}$, two perpendicular canopy diameters $\left(D_{\max }\right.$ and $\left.D_{\min }\right)$, and the first green leaf height $(h)$. The debarking intensity $(D I)$ was estimated as the percentage of trunk debarked and the pruning intensity $(P I)$ through a count of visible scars. Tree vitality was subjectively assessed through a greenness index ( $G I$, 0: no green leaves; 1: green leaves covering less than 50\% of the total canopy; 2: green leaves covering between 50 and $90 \%$ of the canopy; 3: dense and totally green canopy) (Andersen \& Krzywinski 2007). If the nearest tree was more than $100 \mathrm{~m}$ away from the centre, the quarter was considered as vacant, i.e. containing no tree. Inside the quarter area, visible stumps were counted and the three dominant shrub species were noted. $V$. raddiana regeneration was counted by distinguishing seedlings $\left(10 \mathrm{~cm}<H<50 \mathrm{~cm}\right.$ and $\left.c_{0}<12.5 \mathrm{~cm}\right)$ and saplings $(H>50 \mathrm{~cm}$ and $c_{0}<12.5 \mathrm{~cm}$ ). Topography was coded as plain or terrace. Land use was either only pastoral or agro-pastoral (in areas occasionally used for cereal cultivation). Finally, topography and land use were mixed into three land use modalities: (pastoral) terrace, agro-pastoral plain and pastoral plain (no cereal cultivation was practised on terrace). Tree microhabitat was 
determined as floodplain, main channel, secondary channel or interfluve (Stavi et al., 2014).

213 Table 2 shows the number of quarters per land use and microhabitat.

Table 2: Tree species in the 468 quarters and their distribution in land use modalities and

\begin{tabular}{|c|c|c|c|c|c|c|}
\hline & $\begin{array}{l}\text { Vachellia tortilis } \\
\text { subsp. raddiana }\end{array}$ & $\begin{array}{l}\text { Vachellia } \\
\text { flava }\end{array}$ & $\begin{array}{l}\text { Argana } \\
\text { spinosa }\end{array}$ & $\begin{array}{c}\text { Ziziphus } \\
\text { lotus }\end{array}$ & Vacant & Total \\
\hline Terrace & 145 & $\mathbf{0}$ & 8 & $\mathbf{0}$ & 19 & 172 \\
\hline Main channel & 15 & - & 6 & - & 2 & 23 \\
\hline Secondary channel & 65 & - & - & - & - & 65 \\
\hline Floodplain & 65 & - & 2 & - & 2 & 69 \\
\hline Interfluve & - & - & - & - & 15 & 15 \\
\hline Pastoral plain & 148 & $\mathbf{0}$ & 1 & 20 & 34 & 203 \\
\hline Main channel & 35 & - & 1 & 4 & 9 & 49 \\
\hline Secondary channel & 9 & - & - & 1 & - & 10 \\
\hline Floodplain & 104 & - & - & 15 & 25 & 144 \\
\hline Interfluve & - & - & - & - & - & - \\
\hline Agricultural plain & 67 & 1 & 1 & 15 & 9 & 93 \\
\hline Main channel & 2 & - & - & 4 & - & 6 \\
\hline Secondary channel & 2 & - & 1 & 2 & - & 5 \\
\hline Floodplain & 63 & 1 & - & 29 & 9 & 102 \\
\hline Interfluve & - & - & - & - & - & - \\
\hline Total & 360 & 1 & 10 & 35 & 62 & 468 \\
\hline
\end{tabular}

Tree basal area $(B A)$ was calculated as $B A=\sum c_{0} /(4 \pi)$. Total trunk diameter $\left(d_{0}\right)$ was deduced from $B A$ as $d_{0}=\operatorname{sqrt}(4 B A / \pi)$. Canopy was assumed to be an ellipse for the calculation of canopy area as $C A=\pi \cdot D_{\max } . D_{\min } / 4$. A shape index $\left(S I=H / d_{0}\right)$ was defined to characterize the general shape of $V$. raddiana. Because of the presence of vacant quarters, the Warde and Petranka (1981) method was used for tree density calculation. Tree density was defined as $\lambda=C F / R^{2}$ with $C F$ the Warde and Petranka correction factor and $R^{\prime}=\sum 1 /(4 n-n 0) R /\left(4 n-n_{0}\right)$ with $4 n$ the total quarter number, $R$ the distance from the sampling point to the nearest tree, and $n_{0}$ the vacant quarter number. The relative density for a species $i$ was calculated as $\sum n_{i} /\left(4 n-n_{0}\right)$ with $n_{i}$ the number of quarters with the species $i$. A Principal Components Analysis (PCA) was performed from quantitative variables (i.e. $R, d_{0}, H, h, C A, S I, D I, G I$ and $P I$ ) in order to study tree heterogeneity and the contributions of variables.

231 Total regeneration was calculated by summing seedling and sapling numbers. Total 232 Regeneration Rate (TRR) was defined as the ratio between total regeneration and the number of adult trees measured. Established regeneration - and corresponding Established 
Regeneration Rate $(E R R)$ - was calculated from saplings. The debarking probability $(D P)$ was defined as the percentage of debarked trees. Mortality was assessed from the number of visible stumps and dry trees (i.e. greenness index $=0$ ).

Non-parametric Kruskal-Wallis analysis of variance enabled testing of the distribution difference among groups. When the null-hypothesis was rejected, the non-parametric Dunn test was used to identify the stochastic difference between groups. When hypotheses of normal distribution (Shapiro test) and homoscedasticity (Bartlett test) were verified, ANOVA was used instead of Kruskal-Wallis. Correlations were tested with the Spearman test for quantitative variables. The statistical analysis was computed with the $\mathrm{R}$ software [http://www.Rproject.org/]. The null-hypothesis was rejected at a significance level of $5 \%$.

\section{Results}

\subsection{ACACIA STANDS AND HUMAN ACTIVITIES}

\section{$\underline{\text { 3.1.1 Acacia trees and agricultural activities }}$}

Cultivation in the agro-pastoral plain depended on the date of the flood episode and the amount of rainfall. In the study area, on a potential arable area of 1400 ha, the effectively cultivated area was 52.2 ha in 2013 and 173.9 ha in 2014. Cultivation work starts just after the flood episode, between one or two weeks after the rainfall. During the same day, each farmer handsows grains, and then disks his field with a tractor. Tractors are owned by wealthy farmers and are rented to others. All farmers use mechanized disking, and animal-drawn tillage is no longer practised in this area. In both years, the harvest was taken in by hand in May and June, but for more productive years, a combine harvester may be rented in the closest city.

Farmers do not appreciate small acacia trees or other shrubs in their fields, because they represent an obstacle for machines, but they do not systematically remove acacia saplings: "As we don't farm every year, acacia trees grow. We have not farmed here for three years now, and look how many [acacia trees] have grown. It's good to farm this year: if we don't, the whole area will be full of acacia trees" (Taidalt farmer, June 2013). In contrast, they appreciate large acacia trees, mainly for their shade or as windbreaks. To obtain shade, people "clean" trees (i.e. they trim lowest branches) to force them to "rise" (i.e. to develop a distinct canopy) (Fig. 4A). Without any human intervention, farmers consider acacia tree grows as a windbreak (Fig. 4B). Farmers consequently manage tree regeneration during cultivation periods in selecting saplings according to their shape and their location. 

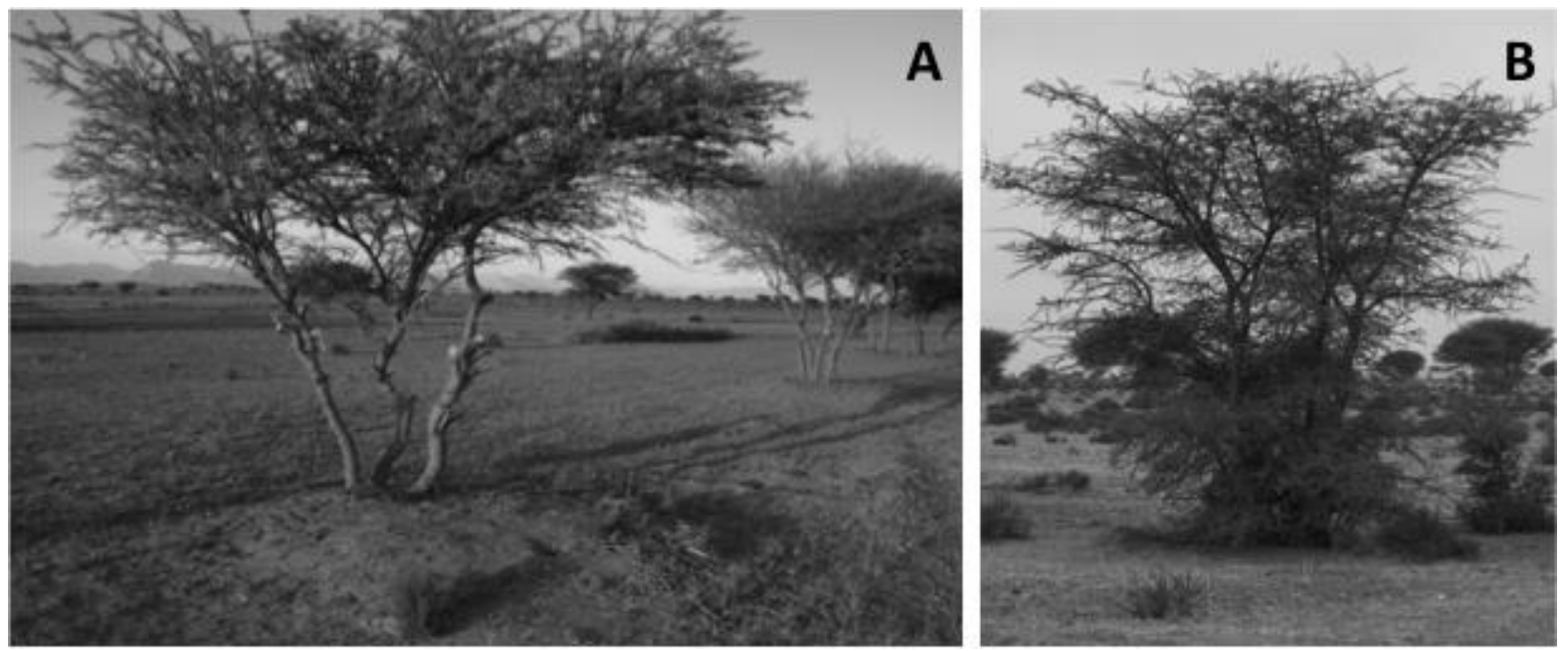

Figure 4: Contrasting management practices of $V$. raddiana trees in the agro-pastoral plain. A: aligned pruned tree dedicated to shade and frontier materialization; B: un-pruned tree acting as a windbreak.

\subsubsection{Acacia trees and pastoral activities}

Like the rest of the study area and despite occasional cultivation, the agro-pastoral plain is essentially a rangeland. $V$. raddiana trees are thus primarily conserved in the agro-pastoral plain for their pastoral value: "If I cut an acacia tree today and a camel or a goat comes tomorrow, what will he [/she] eat?" (Shepherd, February 2014). Both sedentary and semi-nomadic herds browse the area. Sedentary herds for a household do not exceed 20 animals. When grasses and herbs are available, herds are grouped - due to their small size - and given to a paid shepherd who herds them around the village (to a radius of about $10 \mathrm{~km}$ ). In 2013, Taidalt villagers employed three shepherds. One of them, for example, was employed between April and July 2013 by 16 villagers to herd a total of 138 goats and 44 sheep. Semi-nomadic herds of goats and sheep are bigger (from 150 heads) and may include dromedaries. Their pastoral area ranges from the southern border with Mauritania (more than $1000 \mathrm{~km}$ from the study site) to less clearly defined northern limits. They usually do not go further than $100 \mathrm{~km}$ north, except in the case of severe drought. In 2013 and 2014, they were particularly numerous in the study area between March and August, where they settled and grazed, mostly in the plain.

Acacia trees are highly sought by livestock for their mature pods in April-May (period called tawadi) and leaves in August (smeim). They therefore constitute a highly valued standing source of forage in a context of general uncertainty, especially in periods of shortage: "If there is an abundance of herbs, during a wet year, goats won't eat acacia pods between May and August. They will eat only few of them. So, pods stay on the ground and goats will eat them in 
August or September, when herbs are dry" (Herder, February 2014). Herders and shepherds may consequently hang pods and leaves from acacia trees to feed animals. For instance, the shepherd employed in 2013 by settlers in Taidalt went for two days to an area where he was told there were a lot of acacia pods. On this occasion, an iron rod was used to hang pods from acacia trees. Herders used to debark trees in the case of severe drought, especially to feed camels. But all interviewed settlers and semi-nomads affirmed they no longer practised debarking as they preferred buying state-subsidized grain as food complement. This was confirmed by our observations and by the local forester.

\subsubsection{V. raddiana trees exploitation}

Local foresters do not consider the study site as an area of commercial charcoal production. During the survey, only one charcoal burner, in Taidalt village, was identified and observed in his activities. The charcoal burner either prunes or cuts entire living trees with a small axe. Wood is then gathered in a $2 \times 1 \mathrm{~m}$ coalhole with donkey-drawn cart. After a three-hour carbonization process, charcoals cool down for eight hours and are gathered in two to three large bags to be sold in Taidalt village (from 110 to $130 \mathrm{MAD} / \mathrm{bag}$ ). Thus, up to 15 bags a week could be produced. The charcoal producer was active only during periods of unemployment, so the charcoaling activity varied from year to year and over the course of a year.

In addition to commercial charcoal, semi-nomads harvest domestic fuel wood. All informants assert they only prune dry branches, perceived as sufficient to meet domestic needs. This was confirmed by the local forester: "Here in the province, the charcoal production does not represent a big issue. People only produce charcoal for self-consumption. And they mostly use gas. And they mostly use dry and dead branches" (Local forester of Guelmim province, February 2014).

Finally, V. raddiana is a source of medicines for people who use its gum, leaves and pods in the local pharmacopeia. Gum is collected exclusively from exudates during summer. Given the northern location of the study site, people considered that $V$. raddiana does not produce a lot of gum there.

Altogether, these uses and practices may influence, together with environmental factors, several measurable tree and stand parameters (Table 1). 
$V$. raddiana was the dominant tree species with a relative density of $79.6 \%$, associated with Ziziphus lotus in sandy plain (7.5\%) and Argania spinosa (L.) Skeels in terrace (2.1\%). Vacant quarters occupied $13.2 \%$ of the sample (Table 2). Hammada scoparia (found in $94 \%$ of the quarters) and Launaea arborescens (Batt.) Murb. (46\%) dominated the shrub layer. Some species were specific to particular habitats, e.g. Stipagrostis pungens (Desf.) de Winter on sandy soils, Retama raetam (Forssk.) Webb in main riverbeds or Traganopsis glomerata Maire \& Wilczek on rocky terrace soils. Most quarters were located in floodplain microhabitat (Fig. 5) and $77.3 \%$ of them included a $V$. raddiana tree. Secondary channels had the highest probability of including an acacia tree $(96.2 \%)$ while no measurable tree was found in interfluves.

337

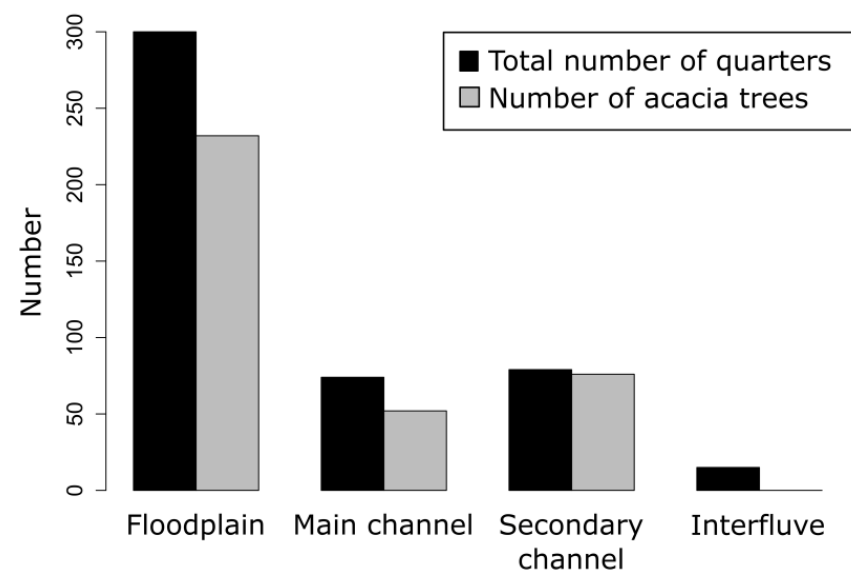

Figure 5: Numbers of quarters and acacia trees by microhabitat.

The two-dimensional projection of $V$. raddiana individuals explained about $60 \%$ of the total variance of the PCA (Fig. 6). Size parameters $\left(C A, d_{0}, H\right)$ contributed to the first axis and explained $45.27 \%$ of the variance. The second axis explained $15.16 \%$ of the variance and was associated with greenness index and debarking intensity. Individuals from the three microhabitats and from the three land use modalities were mixed in the PCA plan (Fig. 6). $V$. raddiana size was mainly influenced by land use and microhabitat; topography had less effect (Table 3). Dunn tests additionally distinguished agro-pastoral plain trees from terrace and pastoral plain trees. Tree vitality and exploitation were affected by land use, microhabitat and topography (Table 3). Dunn tests revealed significant differences in vitality and exploitation between the three land use modalities, the three microhabitats and the two topographic contexts. 


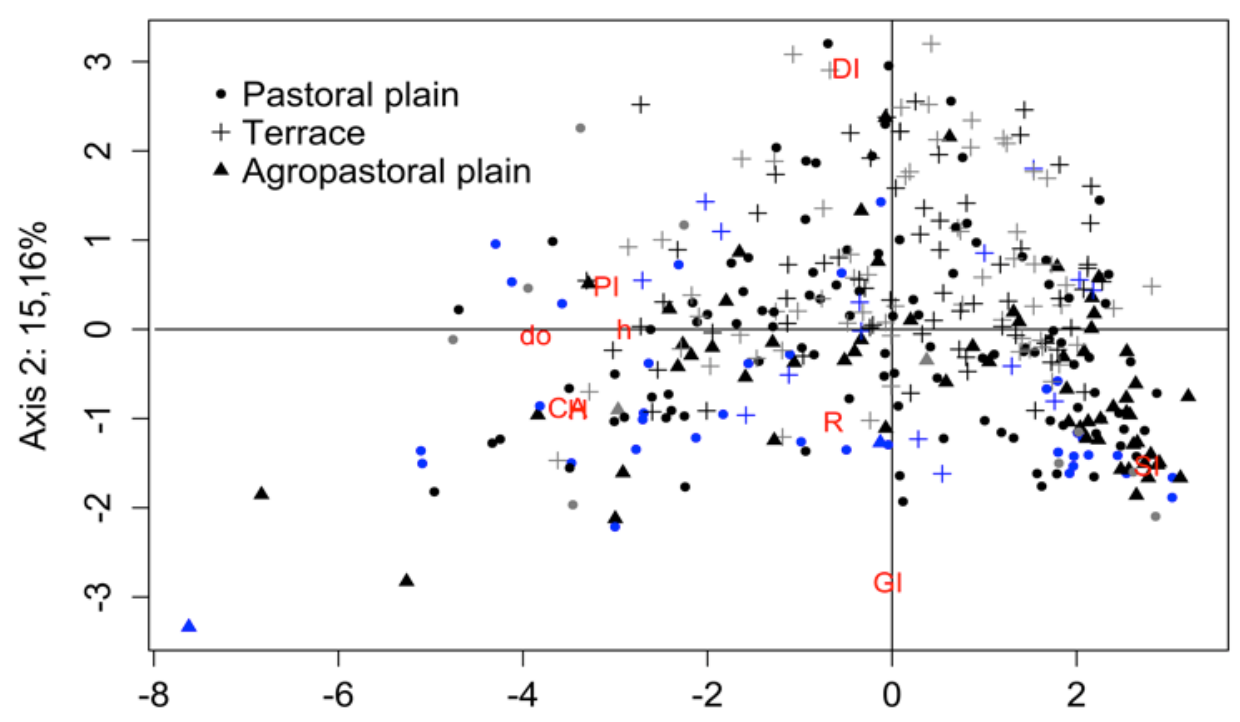

350

351

352

353

354

355

356

357

Table 3: Effects of land use, microhabitat and topography on $V$. raddiana size variables, greenness index, debarking and pruning intensity (Kruskal-Wallis tests p-value)

\begin{tabular}{lcccc}
\hline \hline & & Land use & Microhabitat & Topography \\
\hline & $d_{0}$ & $0.009^{* *}$ & 0.078 & 0.864 \\
& $C A$ & $0.003 * *$ & $0.023^{*}$ & 0.096 \\
Size variables & $H$ & $0.009 * *$ & $0.023^{*}$ & $0.042^{*}$ \\
& $h$ & 0.489 & 0.793 & 0.499 \\
& $S I$ & $<0.001 * * *$ & 0.204 & $<0.001 * * *$ \\
\hline Vitality variable & $G I$ & $<0.001 * * *$ & $<0.001 * * *$ & $<0.001 * * *$ \\
\hline Exploitation & $D I$ & $<0.001 * * *$ & $0.005 * *$ & $<0.001 * * *$ \\
variables & $P I$ & $0.002 * *$ & 0.130 & 0.090 \\
\hline at $<<0.05 ; * *$ significant effect at $\mathrm{p}<0.01 ; * * *$ significant effect at $\mathrm{p}<0.001$.
\end{tabular}

* Significant effect at $\mathrm{p}<0.05$; ** significant effect at $\mathrm{p}<0.01 ; * * *$ significant effect at $\mathrm{p}<0.001$.

\subsubsection{Land use effect on the structure of acacia stands}

$V$. raddiana were small trees with a mean height of $2.9 \mathrm{~m}( \pm 1.3 \mathrm{SD})$ and a maximum height of $9.0 \mathrm{~m}$. Small trees in terms of trunk diameter were predominant in pastoral and agro-pastoral plain (Fig. 7). In terrace, there were fewer $5-10 \mathrm{~cm}$ and $10-15 \mathrm{~cm}$ trunk diameter trees than $15-$ $20 \mathrm{~cm}$ trees. The agro-pastoral plain had the highest ratio of both small trees and the largest trees. Individual parameters varied by land use (Table 4). In terrace and agro-pastoral plain, 
tree heights (Dunn test; $\mathrm{p}=0.45)$ and canopy areas $(\mathrm{p}=0.21)$ were similar, and differed from those of the pastoral plain (all $\mathrm{p}<0.01$ ). Tree diameter differentiated pastoral plain and terrace trees $(\mathrm{p}=0.09)$ from agro-pastoral plain trees (all $\mathrm{p}<0.03)$. Greenness index was similar in pastoral and agro-pastoral plain $(\mathrm{p}=0.28)$ when compared to terrace (all $\mathrm{p}<0.001)$. The shape index was different between the three land use modalities (all $\mathrm{p}<0.03$ ).

The mean distances to the nearest tree $(R)$ were $38.6 \mathrm{~m}( \pm 22.5 \mathrm{SD})$ in terrace, $41.3 \mathrm{~m}( \pm 23.9$ SD) in pastoral plain and $39.2( \pm 22.8 \mathrm{SD})$ in agro-pastoral plain. Corresponding tree densities per hectare were 5.2 in terrace, 4.0 in pastoral plain and 6.1 in agro-pastoral plain. The distance $R$ was influenced by land use (ANOVA; F-value=3.388; $\mathrm{p}=0.035$ ), but differences were significant only between pastoral and agro-pastoral plains (Wilcoxon test; $\mathrm{p}=0.02$ ). The microhabitat also influenced the distance $R$ (Kruskal-Wallis test; $\mathrm{p}<0.001$ ) with mean values of 44.6 ( $\pm 29.3 \mathrm{SD})$ in floodplain, of $56.0( \pm 30.0 \mathrm{SD})$ in main channel and of $39.0( \pm 20.2 \mathrm{SD})$ in secondary channel. The differences were significant between all pairs (Dunn tests; all $\mathrm{p}<0.001$ ), except between floodplain and secondary channel $(\mathrm{p}=0.20)$.

a) Pastoral terrace

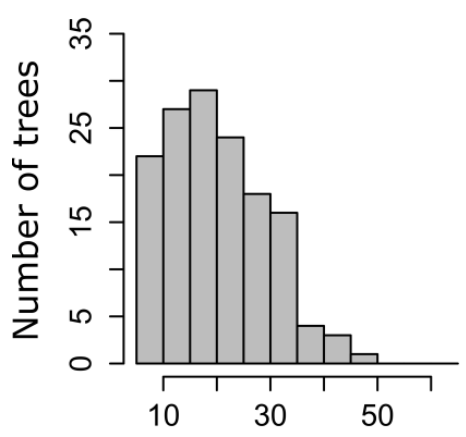

Trunk diameter $(\mathrm{cm})$ b) Pastoral plain

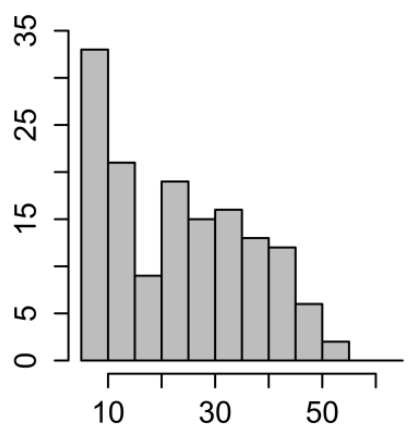

Trunk diameter $(\mathrm{cm})$

\section{c) Agropastoral plain}

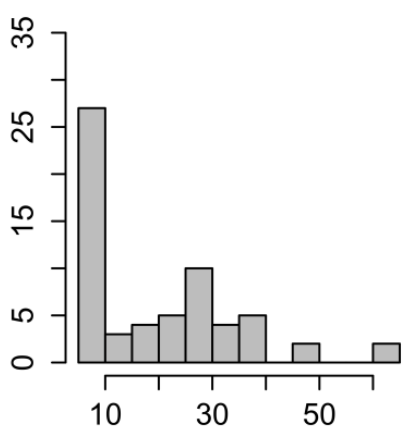

Trunk diameter $(\mathrm{cm})$

Figure 7: V. raddiana tree size distribution by land use (for trees with $d_{0}>5 \mathrm{~cm}$ ).

\subsection{DYNAMICS OF ACACIA STANDS}

\section{$\underline{3.3 .1 V \text {. raddiana regeneration }}$}

Total regeneration was represented by 377 individuals including 205 seedlings and 172 saplings. Regeneration concerned $24 \%$ of terrace, $20 \%$ of pastoral plain and $49 \%$ of agricultural plain quarters; and $28 \%$ of floodplain, $23 \%$ of main channel, $30 \%$ of secondary channel and $20 \%$ of interfluve quarters. Regeneration density was highly heterogeneous with 4.6 individuals/ha $( \pm 17.2 \mathrm{SD})$ in terrace, $4.3( \pm 20.1 \mathrm{SD})$ in pastoral plain and $28.7( \pm 65.5 \mathrm{SD})$ in 
400

401

402

403

404

405

406

407

408

409

410

411

412

413

agro-pastoral plain. Land use significantly influenced regeneration density (Kruskal-Wallis test; $\mathrm{p}<0.001$ ); Dunn test contrasted agro-pastoral plain with pastoral plain and terrace. Conversely, no microhabitat effect on the regeneration density was found (Kruskal-Wallis tests; $\mathrm{p}=0.50$ ). The lowest regeneration rate was in terrace while agro-pastoral plain had the highest score (Table 4).

Table 4: Main $V$. raddiana stand parameters by land use (mean values are given with standard-deviation and Kruskal-Wallis tests p-value)

\begin{tabular}{|c|c|c|c|c|c|}
\hline & & Pastoral terrace & Pastoral plain & Agro-pastoral plain & p-value \\
\hline & $H(\mathbf{m})$ & $2.7 \pm 0.9$ & $3.2 \pm 1.3$ & $3.0 \pm 1.7$ & $\mathrm{p}<0.01$ \\
\hline Size & $d_{0}(\mathrm{~cm})$ & $19.8 \pm 9.2$ & $23.0 \pm 13.3$ & $18.7 \pm 14.5$ & $\mathrm{p}<0.01$ \\
\hline \multirow[t]{2}{*}{ variables } & SI & $0.15 \pm 0.05$ & $0.17 \pm 0.07$ & $0.20 \pm 0.07$ & $\mathrm{p}<0.001$ \\
\hline & $C A\left(\mathrm{~m}^{2}\right)$ & $16.3 \pm 12.3$ & $26.8 \pm 24.3$ & $24.0 \pm 33.1$ & $\mathrm{p}<0.01$ \\
\hline \multirow{2}{*}{$\begin{array}{l}\text { Total } \\
\text { regeneration }\end{array}$} & count & 73 & 69 & 235 & \\
\hline & $T R R$ & $50.3 \%$ & $46.6 \%$ & $350.7 \%$ & \\
\hline \multirow{2}{*}{$\begin{array}{l}\text { Established } \\
\text { regeneration }\end{array}$} & count & 23 & 31 & 118 & \\
\hline & $E R R$ & $15.9 \%$ & $20.9 \%$ & $176.1 \%$ & \\
\hline \multirow{3}{*}{ Mortality } & stumps count & 4 & 7 & 0 & \\
\hline & dead trees & 1 & 0 & 0 & \\
\hline & Mortality rate & $3.4 \%$ & $4.7 \%$ & $0 \%$ & \\
\hline \multirow{5}{*}{$\begin{array}{l}\text { Greenness } \\
\text { index }\end{array}$} & Mean GI & $1.88 \pm 0.55$ & $2.25 \pm 0.69$ & $2.31 \pm 0.58$ & $\mathrm{p}<0.001$ \\
\hline & 0 & $0.7 \%$ & 0 & 0 & \\
\hline & 1 & $20.0 \%$ & $14.2 \%$ & $6.0 \%$ & \\
\hline & 2 & $70.3 \%$ & $46.6 \%$ & $56.7 \%$ & \\
\hline & 3 & $9.0 \%$ & $39.1 \%$ & $37.3 \%$ & \\
\hline
\end{tabular}

\section{$\underline{3.3 .2 \mathrm{~V} \text {. raddiana mortality and human exploitation }}$}

Eleven visible stumps were noted in five quarters (three in terrace and two in pastoral plain) and one dry tree was found, leading to low mortality rates (Table 4). Most wood exploitation was done by pruning and trimming: $60.3 \%$ of $V$. raddiana trees were pruned, with an average of 5.4 ( $\pm 7.0 \mathrm{SD})$ scars per tree. The pruning intensity was influenced by land use (KruskalWallis test; $\mathrm{p}<0.01$ ) but this effect disappeared when corrected by tree size.

The main identified cause of debarking was donkeys. Debarking concerned 122 (33.9\%) V. raddiana trees $(42.1 \%$ of terrace, $35.1 \%$ of pastoral plain and $13.4 \%$ of agro-pastoral plain trees). Debarking probability was dependent on tree size (Kruskal-Wallis test; $\mathrm{p}<0.001$ ). Debarking intensity $(D I)$ was positively correlated with trunk diameter (Spearman test; $\mathrm{p}<0.001 ; \rho=0.26$ ). Debarking concerned between 31.8 and $55.6 \%$ of trees with $d_{o}>15 \mathrm{~cm}$, $11.0 \%$ of the $5-10 \mathrm{~cm}$ trees, and $17.6 \%$ of the $10-15 \mathrm{~cm}$ trees. Land use had no effect on DI after tree size correction (Kruskal-Wallis tests; all p>0.15), except for the trees with $d_{o}<10 \mathrm{~cm}$ 
( $<<0.01$ ), which showed higher $D I$ in terrace than in pastoral and agro-pastoral plains (Dunn test; $\mathrm{p}<0.001)$.

\section{$\underline{3.3 .3 V \text {. raddiana vitality }}$}

Most $V$. raddiana trees had a greenness index of "2" (Table 4). Pastoral and agro-pastoral plains showed a higher percentage of trees with a greenness index of " 3 ” and a lower percentage of trees with a greenness index of " 1 " than terrace (Table 4). Greenness index was not correlated with trunk diameter (Spearman test; $\mathrm{p}=0.54)$ or canopy area $(\mathrm{p}=0.06)$ and was negatively correlated with debarking intensity $(\mathrm{p}<0.001 ; \rho=-0.21)$. Land use influenced greenness index (Kruskal-Wallis test; $\mathrm{p}<0.001$ ); Dunn tests contrasted terrace with agro-pastoral and pastoral plains. The effect of land use on greenness index was significant even after excluding trees with $d_{o}<10 \mathrm{~cm}$ (Kruskal-Wallis test; $\mathrm{p}<0.001$ ), and showed the same discrepancy between terrace and pastoral and agro-pastoral plains. Greenness index correlated with debarking intensity in agro-pastoral (Spearman test; $\mathrm{p}<0.001)$ and pastoral $(\mathrm{p}<0.01)$ plain but not in terrace $(\mathrm{p}=0.82)$. Thus, greenness index depended on both topography and debarking.

\section{Discussion}

\subsection{FUNCTIONS AND STRUCTURE OF $V$. RADDIANA STANDS}

\section{$\underline{4.1 .1 \text { Socio-ecological roles of } V \text {. raddiana }}$}

In the study site, $V$. raddiana trees are spatially and functionally embedded within a complex human subsistence system, which confirms that acacia trees are of major importance for Sahrawi agro-pastoralists (Volpato and Puri, 2014). Farmers use mature man-shaped acacia trees in their fields as shelters against the harshness of the climate (sun and winds), despite their drawbacks in terms of machine accessibility and cereal productivity (Noumi et al., 2011). Trees are also useful for land-ownership identification (Figure 2A) and as an aid to orientation through the plain. One educated villager also mentioned that $V$. raddiana slows down water flow and soil erosion, which nevertheless is not a widespread justification among farmers. However, farmers do not plant nor transplant acacia trees in their fields and the renewal of the tree population seems to be ensured because grain cultivation is occasional. Farmers manage natural regeneration by regulating tree density and by pruning young and mature trees. In doing so, they may consequently influence tree spatial distribution, shape and selection but may not drastically change the spatial patterns of acacia stands through the landscape. 
For herders, $V$. raddiana tree is particularly crucial during the dry season because of (1) its evergreen canopy and (2) its production of leaves and mature pods when forage is scarce (Andersen et al., 2014). V. raddiana presents in this season a high palatability and nutritive value, especially for crude protein requirements (Heneidy, 1996). It has also an indirect forage value through the overall improvement of rangeland understory (Abdallah and Chaieb, 2010). The importance of $V$. raddiana as a valuable resting area for shepherds and animals is also well known (Munzbergova and Ward, 2002). Shepherds used to cut branches and remove bark during severe droughts to feed their animals, especially dromedaries and young goats. The access to state-subsidized food complements could have led to the disappearance of this practice. During tree inventories, no severe canopy damage was observed, which confirmed informant information. Today, state subsidies for animal husbandry in the case of drought could have greatly contributed to the evolution of $V$. raddiana uses and thus may have favoured acacia conservation in these regions. Further socio-economic and historical studies on husbandry may be necessary to confirm this assumption, notably because the access to markets may also have played an important role.

Finally, the $V$. raddiana tree is harvested for firewood, charcoal and medicinal products, which in certain regions constitutes a major obstacle to its conservation (Andersen and Krzywinski, 2007). At the study site, no local regulation legislation is in force while commercial charcoal production is considered as a critical threat by informants. Moroccan forestry legislation forbids wood harvesting, but the implementation of this legislation is however hampered by staff shortages. The weakness of local and governmental institutions regarding tree harvest control and regulation may contribute to the vulnerability of acacia stands and better enforcement is required.

\subsubsection{The heterogeneity of acacia stands}

V. raddiana are small trees forming irregular and scattered stands (Noumi and Chaieb, 2012; Ward and Rohner, 1997). Our measurements of tree height and canopy area were similar to those found in other studies (Lahav-Ginott et al., 2001; Noumi et al., 2010b). In Tunisia, tree density was five trees/ha (Noumi and Chaieb, 2012) and it ranged from 0.4 to 16 trees/ha in the Negev Desert (Andersen and Krzywinski, 2007; BenDavid-Novak and Schick, 1997). Our results indicate comparable densities, influenced by microhabitat and human activities. The microhabitat effect was investigated by Stavi et al. (2014) who suggested that intensive floods, in uprooting trees, may limit tree density in certain microhabitats, such as main channels. Additionally, water and local variation in the runoff regime may have a considerable impact on 
the distribution and density of $V$. raddiana stands (Lahav-Ginott et al., 2001). But other environmental factors may play a role (e.g. soil fertility) and further study would be necessary to address the origin of the microhabitat effect.

Tree inventory revealed a decreasing tree size distribution pattern, indicating a positive trend in $V$. raddiana dynamics. In contrast, the literature more often offered negative perspectives (Noumi and Chaieb, 2012; Ward and Rohner, 1997), except the work of Lahav-Ginott et al. (2001). Our results indicated a weak effect of topography or microhabitat on acacia tree size, in contrast to land use. In the agro-pastoral plain, $V$. raddiana stands contained the biggest trees and showed especially high recruitment rates. In addition, topography had also an effect on recruitment, with lower values in pastoral terrace than in pastoral plain. Thus, at the stand scale, V. raddiana structure was influenced by environmental (i.e. topography and microhabitat) and anthropogenic (i.e. land use) factors. While the agro-pastoral use of the landscape was positively correlated with tree recruitment and density, further study would be required to distinguish the respective roles of environmental and anthropogenic factors.

\subsection{HUMAN INFLUENCE ON ACACIA STAND DYNAMICS}

\subsubsection{V. raddiana regeneration}

With high regeneration density and low mortality rate, our results underlined a regenerative dynamic, especially in the agro-pastoral plain. Tree regeneration in drylands strongly depends on water availability (Larwanou and Saadou, 2005). The germination of $V$. raddiana seeds additionally requires high temperatures (Danthu et al., 2003). Thus, both temporality and intensity of rainfall have to be considered. $V$. raddiana regeneration may also be strongly affected by an alteration of water surface flows (BenDavid-Novak and Schick, 1997; Ward and Rohner, 1997). One may assume that farmers cultivate areas that offer the best water conditions and thus that agro-pastoral plains may have better water status than pastoral lands. In addition, farmers maintain traditional dams and flatten cultivated areas in order to maximize runoff harvesting and the surface area flooded and also to minimize the flow velocity. In addition, tractor disking may contribute to breaking the soil pellicle and increases soil water infiltration, notwithstanding its possible detrimental effects on soil water storage and hydraulic conductivity (McGarry et al., 2000). Overall, land planning for agriculture and farming practices may contribute (1) to burying and protecting seeds, and (2) to creating a favourable microhabitat for germination (Noumi et al., 2010a). Hence, scattered agricultural activities under these extreme conditions may promote acacia regeneration. 
Secondly, moderate browsing is recognized as contributing to the regeneration of $V$. raddiana (Rohner and Ward, 1999), through seed dispersal (Miller, 1996), enhanced germination (Danthu et al., 2003) and trampling (Noumi et al., 2010b). Unfortunately, the influence of browsing is difficult to assess in a field snapshot for mobile and open-access systems (Andersen and Krzywinski, 2007), which prevented us from studying the direct effect of browsing. Nevertheless, our results showed that $V$. raddiana regeneration, establishment and survival were effective under the observed agro-pastoral practices. This suggests a sustainable use of $V$. raddiana trees within the framework of the current agro-pastoral system. To go further in the understanding of acacia regenerative dynamics in this area, it would be necessary to investigate (1) the effect of domestic herds on seed dispersal, germination and seedling survival and (2) the effect and intensity of seed predation by insects (Derbel et al., 2007), which is a major issue for $V$. raddiana regeneration elsewhere (Noumi et al., 2010a).

\subsubsection{V. raddiana mortality and human exploitation}

High $V$. raddiana mortality (up to 16.8\%) was reported in the Negev Desert (Stavi et al., 2014). Considering our contrasting results, $V$. raddiana mortality may be a problem specific to that area. Mortality may be related to climate change (Stavi et al., 2014), road construction (Ward and Rohner, 1997) or charcoal production (Andersen and Krzywinski, 2007). In our case, charcoal production (assessed from visible stumps) induced most tree death but remained weak. The low mortality rates, following three successive dry years, highlight the high tolerance of $V$. raddiana to drought (Andersen et al., 2014). Informant information corroborates that acacia trees rarely die from drought, but this would require further specific studies to be better understood.

Debarking affected one third of acacia trees. All informants (from local people to foresters) suggested that debarking trees to feed animals is no longer practised and that current debarking was mainly caused by donkeys. Consistently with MacGregor and O'Connor (2004), we found that debarking was correlated with tree size and was unlikely to cause tree death. Only partial debarking was observed, which may not be sufficient to kill trees (Moncrieff et al., 2008). Debarking had however an impact on canopy greenness in plain, in contrast to terrace. In assuming that water availability is the main limiting factor for acacia tree vitality (Wiegand et al., 2000a), the effect of debarking may be visible when water becomes less constraining. Debarking may thus affect tree growth (Scogings and Macanda, 2005) and increase water stress, contributing to tree vulnerability in the face of severe drought. Furthermore, small trees were more often debarked in terrace than in plain. Because of lower vitality and higher water scarcity, 
an acacia tree in terrace may be older than a same-sized acacia in plain (Martin and Moss, 1997). Small terrace trees may consequently have been longer exposed to bark predators (either people or animals) than plain trees. The access to the trunk may also influence debarking. Because of their higher vitality in plain, small $V$. raddiana trees had higher canopy density and a bushier configuration there (pers. obs.). Small terrace tree trunks may thus be more accessible. Finally, debarking depends on the animals' preferences and forage availability (Scogings and Macanda, 2005), which may be lower in terrace.

\subsection{PERSPECTIVES FOR RESEARCH ON SAHARAN ACACIA TREES}

\subsubsection{Acacia trees and people: a currently sustainable cohabitation?}

Assessing the effect of human practices on tree ecology remains a challenge as measurable tree parameters are also influenced by numerous other environmental factors (e.g. greenness index depends on human exploitation and on drought harshness levels, tree density depends on tree removal and selection by people and on abiotic factors, etc.). This study however showed that altogether, the socio-ecological roles of $V$. raddiana encourage Sahrawi agro-pastoralists to conserve, protect and shape trees. The management practices of acacia trees in the agro-pastoral plain, together with environmental factors, resulted in relatively dense and, at the time of the study, regenerating tree stands. In addition, current wood exploitation did not represent a threat to the sustainability of $V$. raddiana trees, despite the powerlessness of the regulatory authorities. Clearly, snapshot studies constitute a starting point to the understanding of drylands, because of the high stochasticity and the low predictability of environmental factors and of tree stands dynamics (Wiegand et al., 2000b). Moreover, as those dynamics commonly differ between local sites (Lahav-Ginott et al., 2001), other locations should be investigated by further research. For instance, the southern Draa Hamada, an area regionally known as a place of high charcoal production, may show dissimilar dynamics. However, restricted access, for reasons of safety and political instability, hampers such research. Thus, further long-term and multi-site studies are required to assess the sustainability of $V$. raddiana stands in the Saharan region. In addition, such studies should pay particular attention to the mixed effects of human and environmental factors on tree stands dynamics.

\subsubsection{The rural forest paradigm to better address dryland forest management?}

In underlining the simultaneous influence of anthropogenic and environmental factors on $V$. raddiana trees and the importance of this species for local activities, our results suggest that $V$. 
raddiana stands could be considered as rural forests (sensu Genin et al., 2013). Firstly, V. raddiana ensures livelihood-sustaining functions through its multipurpose role for people (sheltering function, wood and forage provision, medicines, cultural). Secondly, V. raddiana trees are managed in a multipurpose perspective, especially by farmers who shape them and manage selection and regeneration. Thirdly, $V$. raddiana constitutes a secure and predictable resource for herders, i.e. a living capital to better cope with drought and uncertainty. Finally, as in the case of rural forests (Genin et al., 2013; Michon et al., 2007), V. raddiana stands are (1) managed, shaped and transformed by Saharan rural societies; (2) fully integrated within farming and pastoral systems; and (3) structure-building components of rural landscapes and production systems.

The framework of analysis of the rural forest paradigm may contribute to better distinguishing the respective influence of human and environmental factors on tree stands structure and dynamics in drylands. This is particularly crucial in order to bring desertification and dryland degradation under control and as a basis for determining appropriate conservation policies. One of the current challenges in monitoring desertification and its causes is to use accurate indicators of long-term trends, such as slow variables (Carpenter and Turner, 2001). In contrast with annual plants, trees have a slow response to short-term climatic variations and may constitute an indicator of dryland ecosystem state and degradation. Notably, as ecological keystone species (Munzbergova and Ward, 2002; Noumi et al., 2012), V. raddiana trees may be a good proxy to assess overall ecosystem sustainability (Grouzis and Le Floc'h, 2003). Furthermore, $V$. raddiana stand monitoring may provide a basis for assessing patterns of change in climatic or human exploitation. Rural forest paradigm and associated integrated approaches (as suggested Reynolds et al., 2007) may thus improve our understanding of desertification processes and may help in implementing effective measures to deal with this environmental and social issue.

\section{Conclusion}

The aim of this work was to assess the structure and dynamics of Saharan acacia stands and to better understand the influence of human activities. Our results emphasized the practices of Sahrawi farmers and herders who shape individual trees and their influence on $V$. raddiana stand structure and dynamics. In exchange, $V$. raddiana provides a broad range of provisioning ecosystem services that may influence local subsistence strategies. Far from being a binary exploitation / degradation relationship, current Saharan agro-pastoralism cannot be described 
as an unsustainable use of $V$. raddiana trees. On the contrary, acacia stands were in a positive regenerative dynamic, in spite of browsing and cultivation. While national forest management and conservation plans in Morocco are based on the regulation, or even exclusion, of human activities because of their deleterious effects (Aubert, 2013), our results plead against this widespread approach. Further studies would be required to better understand the complex nature of the relationships between $V$. raddiana and the Sahrawi society on the one hand, and to better distinguish the respective impact of anthropogenic and environmental factors on the other hand. In a context of forthcoming harsher climatic conditions, such studies are crucial to provide better information on socio-ecosystem issues and challenges regarding $V$. raddiana and to plan efficient conservation policies that will satisfy both ecological and socio-economic priorities.

\section{Acknowledgements}

We would like to thank IRD (VIR funding), the Med-Inn-Local program of the ANR (Agence Nationale pour la Recherche, France) for the funding provided for this research ( ${ }^{\circ}$ ANR-12TMED-0001-01), and LMI MediTer and the Cadi Ayyad University of Marrakech for technical and logistical support, particularly Geneviève Michon, Florence Pinton, Hassan Kamil and Mohamed Alifriqui for their sounded advice and expertise. We are grateful to the inhabitants of Taidalt village for their cooperation and especially to Hassan Bouchrouaat for his precious help as a translator and a key facilitator.

\section{References}

Abdallah, F., Chaieb, M., 2010. Interactions of Acacia raddiana with herbaceous vegetation change with intensity of abiotic stress. Flora 205, 738-744.

Abdallah, F., Noumi, Z., Touzard, B., Belgacem, A.O., Neffati, M., Chaieb, M., 2008. The influence of Acacia tortilis (Forssk.) Subsp. raddiana (Savi) and livestock grazing on grass species composition, yield and soil nutrients in arid environments of South Tunisia. Flora Morphol. Distrib. Funct. Ecol. Plants 203, 116-125.

Andersen, G.L., Krzywinski, K., 2007. Mortality, recruitment and change of desert tree populations in a hyper-arid environment. PLoS One 2, e208. 
Andersen, G.L., Krzywinski, K., Talib, M., Saadallah, A.E.M., Hobbs, J.J., Pierce, R.H., 2014.

Aubert, P., 2013. Les évolutions de la politique forestière au Maroc : entre réappropriation du

Belsky, A.J., Amundson, R.G., Duxbury, J.M., Riha, S.J., Mwonga, S.M., 1989. The effects of trees on their physical, chemical and biological environments in a semi-arid savanna in Kenya.

662

BenDavid-Novak, H., Schick, A.P., 1997. The response of Acacia tree populations on small 664 alluvial fans to changes in the hydrological regime: Southern Negev Desert, Israel. Catena 29, 665 $341-351$.

666

667

Carpenter, S.R., Turner, M.G., 2001. Hares and Tortoises: Interactions of Fast and Slow 668 Variablesin Ecosystems. Ecosystems 3, 495-497.

669

Danthu, P., Roussel, J., Neffati, M., 2003. La graine et la germination d'Acacia raddiana, in:

Grouzis, M., Le Floc'h, E. (Eds.), Un Arbre Au Désert: Acacia Raddiana. IRD Editions, Paris, 672 pp. 265-284.

673

674

Derbel, S., Noumi, Z., Werner Anton, K., Chaieb, M., 2007. Life cycle of the coleopter 675 Bruchidius raddianae and the seed predation of the Acacia tortilis Subsp. raddiana in Tunisia. C. R. Biol. 330, 49-54.

677

Genin, D., Aumeeruddy-Thomas, Y., Balent, G., Nasi, R., 2013. The Multiple Dimensions of Rural Forests: Lessons from a Comparative Analysis. Ecol. Soc. 18, 27.

680

Genin, D., Simenel, R., 2011. Endogenous Berber Forest Management and the Functional 682 Shaping of Rural Forests in Southern Morocco: Implications for Shared Forest Management 683 Options. Hum. Ecol. 39, 257-269.

684

Grouzis, M., Le Floc'h, E., 2003. Un arbre au désert : Acacia raddiana. IRD Editions, Paris. 
686

687

688

689

690

691

692

693

694

695

696

697

698

699

700

701

702

703

704

705

706

707

708

709

710

711

712

713

714

715

716

717

718

Helldén, U., Tottrup, C., 2008. Regional desertification: A global synthesis. Glob. Planet. Change 64, 169-176.

Heneidy, S.Z., 1996. Palatability and nutritive value of some common plant species from the Aqaba Gulf area of Sinai, Egypt. J. Arid Environ. 34, 115-123.

Herrmann, S.M., Hutchinson, C.F., 2005. The changing contexts of the desertification debate. J. Arid Environ. 63, 538-555.

Hobbs, J.J., Krzywinski, K., Andersen, G.L., Talib, M., Pierce, R.H., Saadallah, A.E.M., 2014. Acacia trees on the cultural landscapes of the Red Sea Hills. Biodivers. Conserv. 23, 29232943.

Kyalangalilwa, B., Boatwright, J.S., Daru, B.H., Maurin, O., van der Bank, M., 2013. Phylogenetic position and revised classification of Acacia s.l. (Fabaceae: Mimosoideae) in Africa, including new combinations in Vachellia and Senegalia. Bot. J. Linn. Soc. 172, 500523.

Lahav-Ginott, S., Kadmon, R., Gersani, M., 2001. Evaluating the viability of Acacia populations in the Negev Desert: a remote sensing approach. Biol. Conserv. 98, 127-137.

Lamprey, H., 1975. Report on the desert encroachment reconnaissance in northen Sudan: 21 october to 10 November, 1975. Reprinted in Desertification Control Bulletin 11, 1-7.

Larwanou, M., Saadou, M., 2005. Biodiversity of ligneous species in semi-arid to arid zones of southwestern Niger according to anthropogenic and natural factors. Agric. Ecosyst. Environ. 105, 267-271.

Le Houérou, H.N., 1990. Définition et limites bioclimatiques du Sahara. Sécheresse 1, 246259.

MacGregor, S.D., O’Connor, T.G., 2004. Response of Acacia tortilis to utilization by elephants in a semi-arid African savanna. South African J. Wildl. Res. 34, 55-66. 
Martin, D., Moss, J., 1997. Age determination of Acacia tortilis (Forsk.) Hayne from northern Kenya. Afr. J. Ecol. 35, 266-277.

McGarry, D., Bridge, B.J., Radford, B.J., 2000. Contrasting soil physical properties after zero and traditional tillage of an alluvial soil in the semi-arid subtropics. Soil Tillage Res. 53, 105115 .

MEA, 2005. Ecosystems and Human Well-being: Desertification Synthesis. Washington D.C.

Michon, G., de Foresta, H., Levang, P., Verdeaux, F., 2007. Domestic forests : a new paradigm for integrating local communities' forestry into tropical forest science. Ecol. Soc. 12, 1.

Miller, M.F., 1996. Dispersal of Acacia seeds by ungulates and ostriches in an African savanna. J. Trop. Ecol. 12, 345-356.

Moncrieff, G.R., Kruger, L.M., Midgley, J.J., 2008. Stem mortality of Acacia nigrescens induced by the synergistic effects of elephants and fire in Kruger National Park, South Africa. J. Trop. Ecol. 24, 655-662.

Monteil, V., 1948. Notes sur les Tekna, Editions L. ed. Institut des Hautes Etudes Marocaines, Paris.

Msanda, F., El Aboudi, A., Peltier, J.P., 2002. Originalité de la flore et de la végétation de l'Anti-Atlas sud-occidental (Maroc). Feddes Repert. 113, 603-615.

Munzbergova, Z., Ward, D., 2002. Acacia trees as keystone species in Negev desert ecosystems. J. Veg. Sci. 13, 227-236.

Niamir-Fuller, M., 1998. The resilience of pastoral herding in Sahelian Africa, in: Berkes, F., Folke, C. (Eds.), Linking Social and Ecological Systems: Management Practices and Social Mechanisms for Building Resilience. Cambridge University Press, pp. 250-284. 
Noumi, Z., Abdallah, F., Torre, F., Michalet, R., Touzard, B., Chaieb, M., 2011. Impact of Acacia tortilis ssp. raddiana tree on wheat and barley yield in the south of Tunisia. Acta Oecologica 37, 117-123.

Noumi, Z., Abdallah, L., Touzard, B., Chaieb, M., 2012. Acacia tortilis (Forssk.) subsp. raddiana (Savi) Brenan as a foundation species: a test from the arid zone of Tunisia. Rangel. J. $34,17-25$.

Noumi, Z., Chaieb, M., 2012. Dynamics of Acacia tortilis (Forssk.) Hayne subsp. raddiana (Savi) Brenan in arid zones of Tunisia. Acta Bot. Gall. 159, 121-126.

Noumi, Z., Ouled Dhaou, S., Abdallah, F., Touzard, B., Chaieb, M., 2010a. Acacia tortilis subsp. raddiana in the North African arid zone: the obstacles to natural regeneration. Acta Bot. Gall. 157, 231-240.

Noumi, Z., Touzard, B., Michalet, R., Chaieb, M., 2010b. The effects of browsing on the structure of Acacia tortilis (Forssk.) Hayne ssp. raddiana (Savi) Brenan along a gradient of water availability in arid zones of Tunisia. J. Arid Environ. 74, 625-631.

Reynolds, J.F., Smith, D.M.S., Lambin, E.F., Turner, B.L., Mortimore, M., Batterbury, S.P.J., Downing, T.E., Dowlatabadi, H., Fernández, R.J., Herrick, J.E., Huber-Sannwald, E., Jiang, H., Leemans, R., Lynam, T., Maestre, F.T., Ayarza, M., Walker, B., 2007. Global desertification: building a science for dryland development. Science 316, 847-51.

Rohner, C., Ward, D., 1999. Large Mammalian Herbivores and the Conservation of Arid Acacia Stands in the Middle East. Conserv. Biol. 13, 1162-1171.

Sahraoui, B., Ait Mohand, L., Echaib, B., 1996. Evolution spatio-temporelle des peuplements d'Acacacia tortilis (Forsk.) Hayne raddiana (Savi) Brenan dans les monts Ougarta (Sahara nordoccidental). Sécheresse 7, 173-178.

Scogings, P., Macanda, M., 2005. Acacia karroo responses to early dormant season defoliation and debarking by goats in a semi-arid subtropical savanna. Plant Ecol. 179, 193-206. 
785 Sparks, J.C., Masters, R.E., Payton, M.E., 2002. Comparative Evaluation of Accuracy and 786 Efficiency of Six Forest Sampling Methods. Proc. Oklahoma Acad. Sci. 82, 49-56.

787

788 Stavi, I., Silver, M., Avni, Y., 2014. Latitude, basin size, and microhabitat effects on the 789 viability of Acacia trees in the Negev and Arava, Israel. Catena 114, 149-156.

790

791 Volpato, G., Puri, R.K., 2014. Dormancy and Revitalization: The fate of ethnobotanical 792 knowledge of camel forage among Sahrawi nomads and refugees of Western Sahara. Ethnobot. 793 Res. Appl. 12, 183-210.

794

795

Ward, D., Rohner, C., 1997. Anthropogenic causes of high mortality and low recruitment in 796 three Acacia tree taxa in the Negev desert, Israel. Biodivers. Conserv. 6, 877-893.

797

798 Warde, W., Petranka, J.W., 1981. A correction factor table for missing Point-Center Quarter 799 data. Ecol. Soc. Am. 62, 491-494.

800

801 Wiegand, K., Jeltsch, F., Ward, D., 2000a. Do spatial effects play a role in the spatial 802 distribution of desert-dwelling Acacia raddiana ? J. Veg. Sci. 11, 473-484.

803

804 Wiegand, K., Ward, D., Thulke, H.H., Jeltsch, F., 2000b. From snapshot information to long805 term population dynamics of Acacias by a simulation model. Plant Ecol. 150, 97-114. 